\title{
Conf- $720316--1$
}

GAS-COOLED POWER REACTORS AND THEIR THERMAL FEATURES ${ }^{1}$

P. R. Kasten ${ }^{2}$ and D. B. Trauger ${ }^{3}$

I shall review the salient features of helium-cooled reactors for electric power generation. Two designs are important in the United States the high-temperature gas-cooled reactor (HTGR) and the gas-cooled fast breeder reactor (GCFBR). The HTGR uses a graphite core structure containing carbon coated fuel particles of uranium and thorium oxides or carbides in a unique fuel element design. The reactor operates with neutrons in the thermal energy spectrum. The GCFBR fuel is as oxide pellets of uranium and plutonium clad with stainless steel. The fuel elements are similar to those for water and sodium cooled reactors. As the name indicates, it operates in the fast neutron spectrum. After a brief introduction, 1 will emphasize the thermal features of these reactors, including some problem areas which hopefully are of interest to heat $t$ ransfer specialists.

GCRs have been under development in the United States since 1957. A 330-MW(e) prototype HTGR power plant, the Fort St. Vrain reactor, is presently under construction near Denver, Colorado. Both 780-MW(e) and 1100-MW(e) plants are available from Gulf General Atomic and four units have been sold during the past six months. Extensive experience exists in Europe with other types of gas-cooled reactors and with two HTGR experiments. In 1967, Philadelphia Electric Company placed into operation a 40-MW(e) experimental HTGR, the Peach Bottom Atomic Power Station Unit 1. It has operated commercially since that time with very good performance for both the gas coolant equipment and the core. Table 1 briefly summarizes some of the design and operating features of the Peach Bottom, Fort St. Vrain and large HTGR units. Whereas the HTGR is now commercially available, the GCFBR is in a relatively early stage of development.

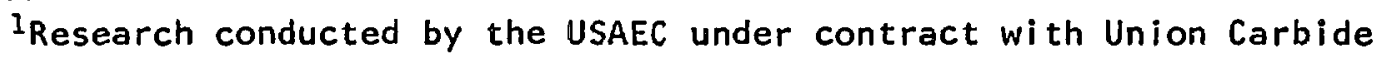
Corporation.

${ }^{2}$ Director, Gas-Cooled Reactor and Thorium Utilization Programs, Oak Ridge National Laboratory, Oak Ridge, Tennessee.

${ }^{3}$ Associate Director, Oak Ridge National Laboratory, Oak Ridge, Tennessee.
}

Paper prepared for panel on "Powep Generation in the Neap Putupell at the - 8th Annual Southeastern Seminar on Thermal Sciences at Vandept N Univapsity, March.23, 1972. 
EVOLUTION OF HTGR NUCLEAR STEAM SYSTEM

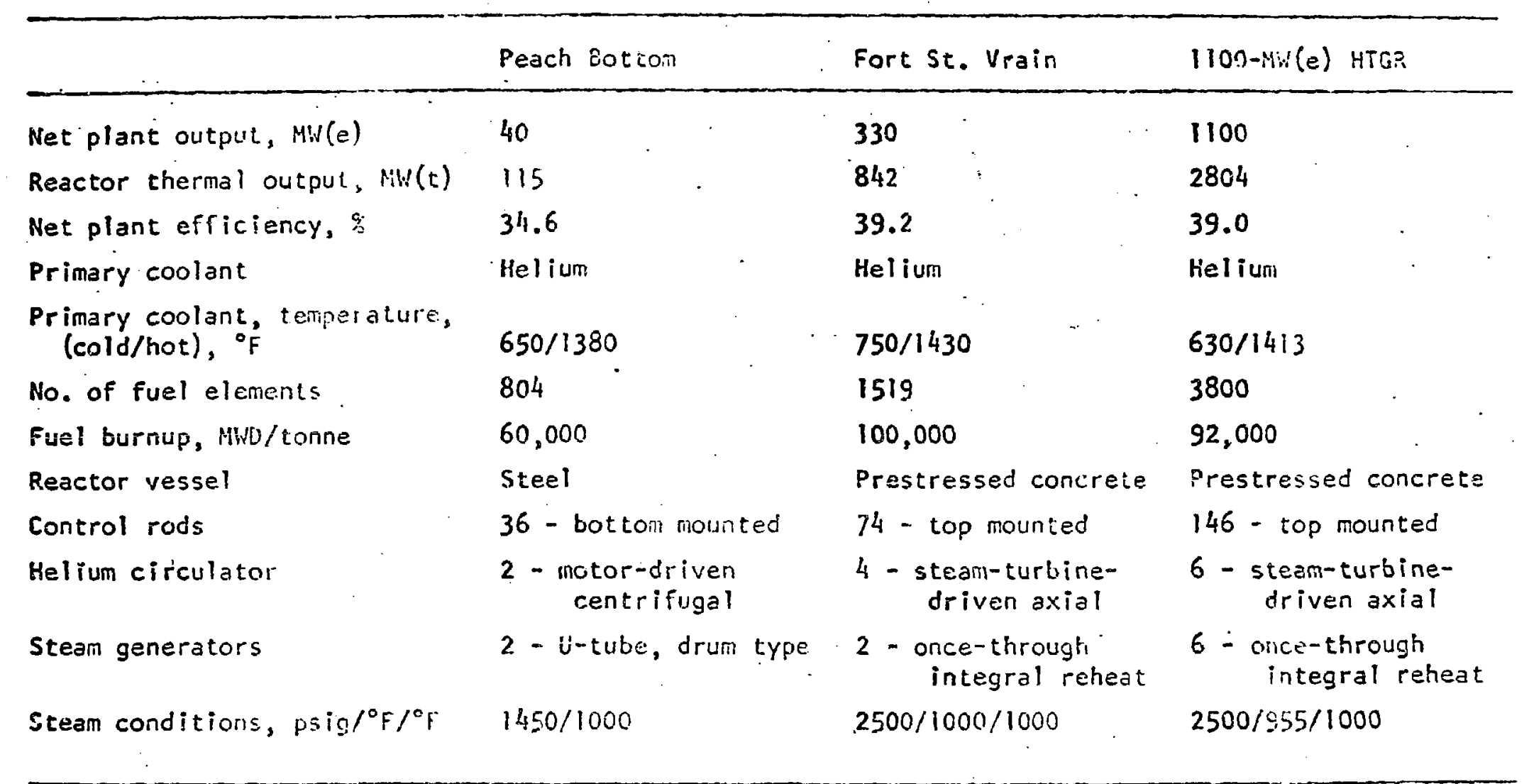

\section{-NOTICE}

This report was prepared as an account of work sponsored by the United States Government. Neither the United States nor the United States Atomic Energy Commission, not any of their employees, nor any of their contractors; subcontractors, or thes employees, makes any warranty, oxpress or for the or acury, pleteness or usefuines of any information, apparitus, pleteness or usefulness or any infersents 作 
These two reactor concepts have common features insofar as both make use of helium as the coolant and thereby use similar components in the gas circuit including heut exchangers, circulators, and prestressed concrete reactor vessels. Thus development of HTGRs is useful in developing this breeder reactor technology. In addition, the GCFBR profits from the fuel development and testing facilities of the Liquid Metal Fast Breeder Reactor program for which a demonstration plant is to be built in Tennessee. As 1 am sure you know, development of economic fast breeder reactors will greatly extend our ability to economically utilize nuclear fuel resources.

The HTGR shows promise for operation at temperatures high enough so a helium turbine can be profitably employed to drive the steam generator. This could permit economic use of dry cooling towers with an attendarit reduction in thermal pollution effects and improved reactor siting. It also appears that HTGR fuels can be developed for operation at temperatures high enough for process heat applications such as coal gasification.

HTGRs are generally proposed for operation on the thorium fuel cycle, using uranium of high enrichment as the initial and makeup fissile material. ${ }^{233} \mathrm{U}$ produced by neutron capture from thorium is recycled to the reactor system. GCFBRs are generally proposed for operation on the uranium cycle with plutonium being used as the fissile fuel and 2380 as the fertile material. The product plutonium is recycled. Further, HTGRs can utilize plutonium as the makeup fissile fuel, thus GCFBRs producing excess plutonium (or $233 \mathrm{U}$ ) and HTGRs car work together in a symbiotic system.

The sishematic flow diagrams of the steam and coolant systems for GCRs are indicated in Fig. 1. As shown, steam from the high pressure turbine drives the helium circulators of the coolant circuit, which provides a compact, highly reliable motive power for the circulators.

The general arrangement of a 1100-MW(e) commercial HTGR is shown in Fig. 2. The heat exchangers are in a pod arrangement surrounding the core, all housed within the prestressed concrete pressure vessel. The PCRV is stressed by wire-wrapping the cylinder and utilizing anchored vertical tendons. Helium enters the reactor at the top and flows downward through the core. The coolant enters the steam generator at the bottom, and makes 


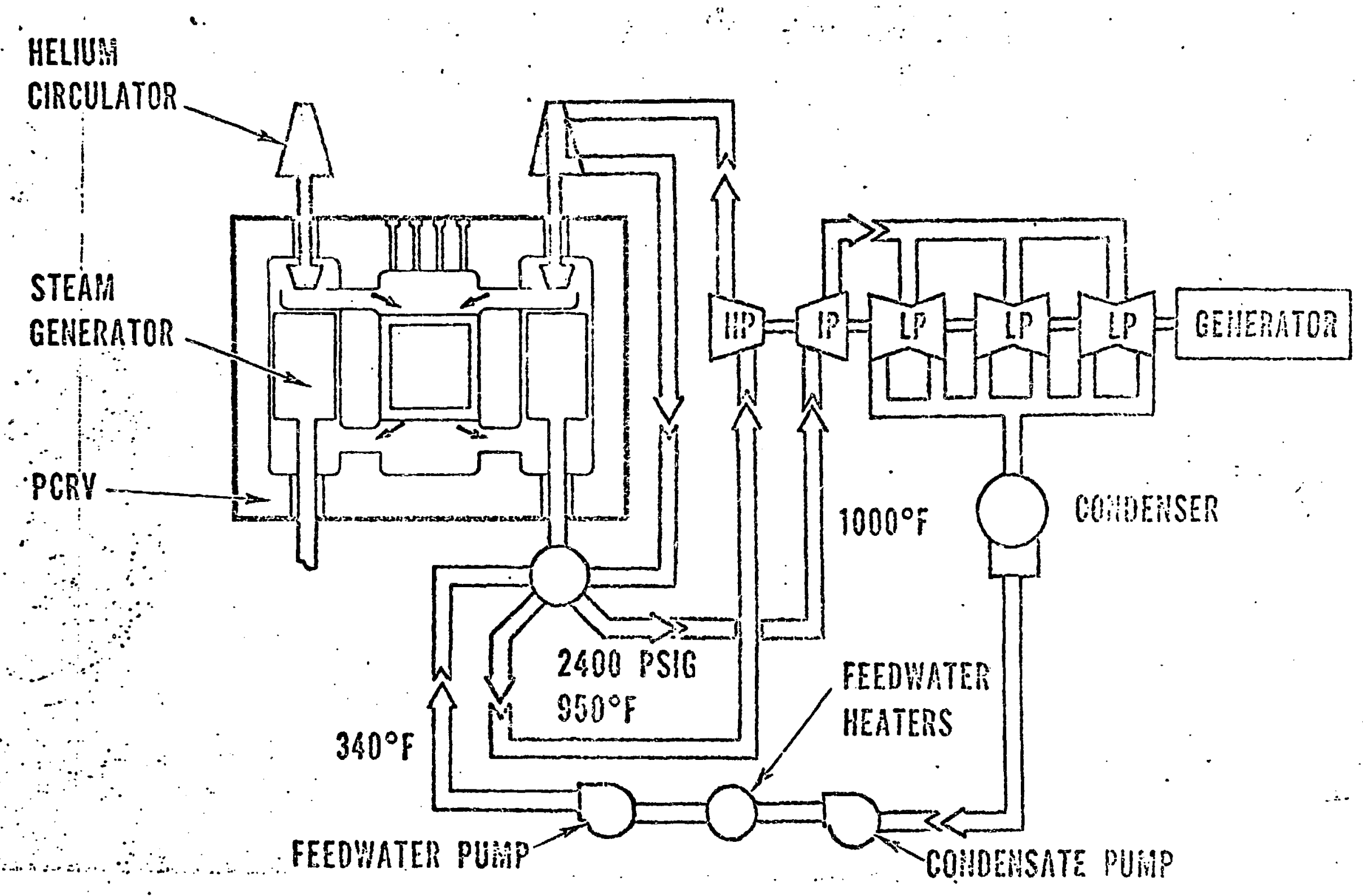

HTGR Schematic Flow Diagram 
LARGE HTGR GENERAL ARRANGEMENT
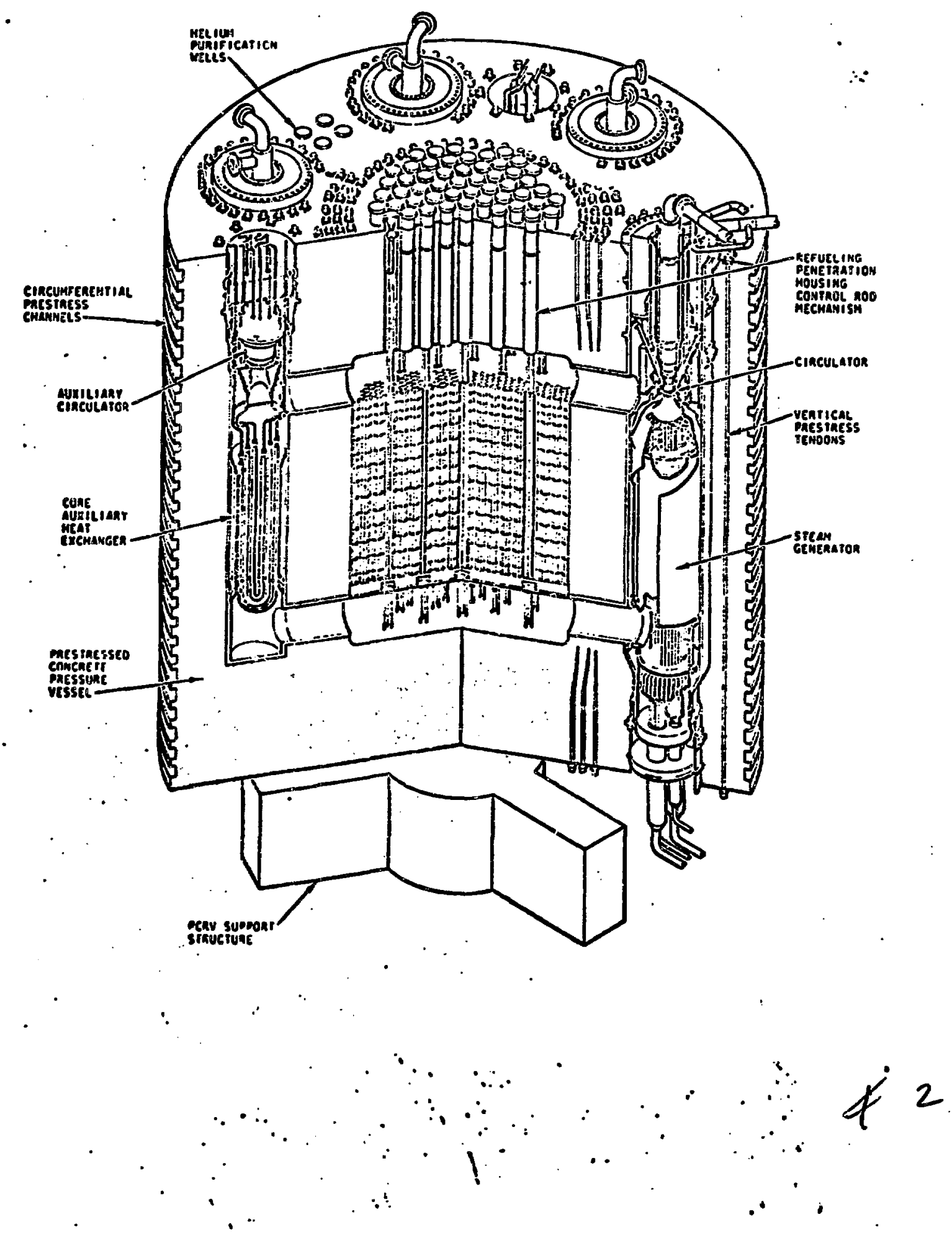
several passes in a once-through steam flow design. There are six primary gas circulators and steam generators; in addition, there are three auxiliary coplant heat exchanger circuits for removing radioactive decay heat energy in case of loss of primary cooling capacity.

In internal steel liner within the PCRV serves as a sealing membrane; penetrations and closures provide acees;s to the cavities of the vessel. The PCRV is protected by a thermal barpler between the high temberature hel fum and the liner. Flaure 3 shows sthematically the insulation. liner, and cooling arrangements in section for the upper olenum of the reactor cavity. The cooling tubes attached to the steel liner remove heat and maintain the concrete at a peak temperatura less than $150^{\circ} \mathrm{F}$. In the higher temperature reglons of the cireult, additional insulation. is required.

Continuing development work is deslrable"to improve Insulation materials and particularly to demonstrate their lona-term performance eapabilities in gas-cooled reactor enviroments. Development work should include measurement of thermal conductivity, thermal cycling tests of varlous materials, and studies of thermal grablitify on wear-resistant surface coatings. 'Some excellent work is being done in both france and England. Four types of insulation have been employed in PCRV application. These ore: the fibrous ceramis. reflective metal metallic gauze, and pumice concrete. Silica foam, alumina foan, and graphite cloth are promising materials for very high temperatures.

Returning to the reactor core, FIg. 411 lustrates a basic fuel partlele, and a fuel element. The latter. consists of a hexagonal graphite block about $14 \mathrm{in}$. aeross the flats and $31 \mathrm{ln}$. long; the block contairs 108 epolant holes $5 / 8 \mathrm{in}$. In diam, and 210 fuel holes $: / 2$ in. in diem. The fuel partleles have a kernel about $400 \mu \mathrm{In} \mathrm{d} \mathrm{am}$, and surrounding the kernel are four layers of coatings, consisting of an inner buffer layer of porous pyrolytic carbon (for absorbing fission recolls and providing space for gaseous fission products), a second layer of dense isotropic pyrolytic earbon, a layer of silicon carbide (for retaining metal fission products such as Sr and (s) and an outer layer of dense Isotropic pyrolytic carbon. The cooted fuel particles are blended with pltch and graphite flour, and pressed Into rods about 2 in. long and $1 / 2 \mathrm{in}$. In diam. The rods are heat treated prior to loading into the fuel block. The fuel assemblies are placed together to form the core as Indicated In Fig. 5. 


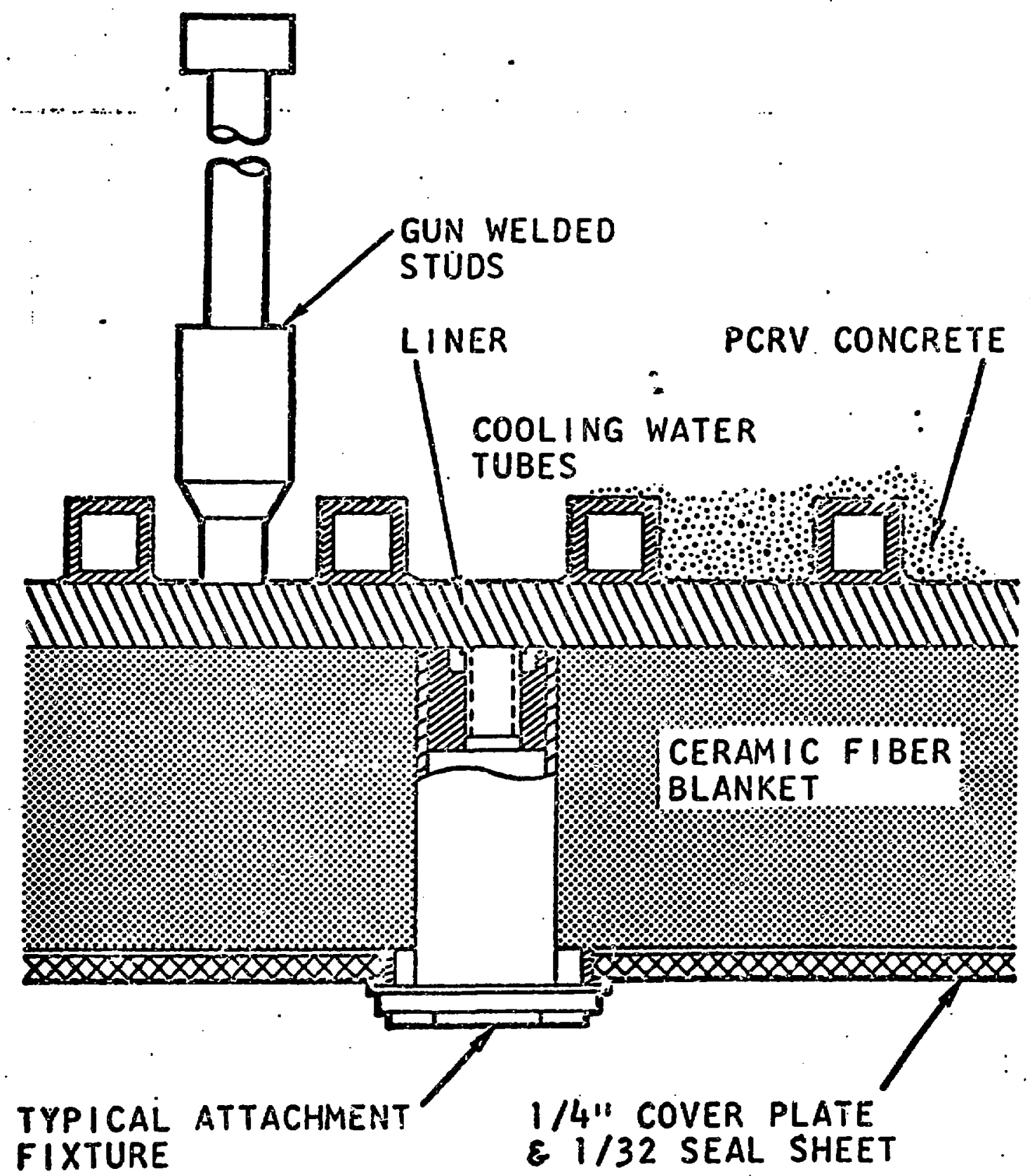

Typical Liner and Thermal Barrier Cross Section in the lpper Plenum 


\section{MTGR FUEL}
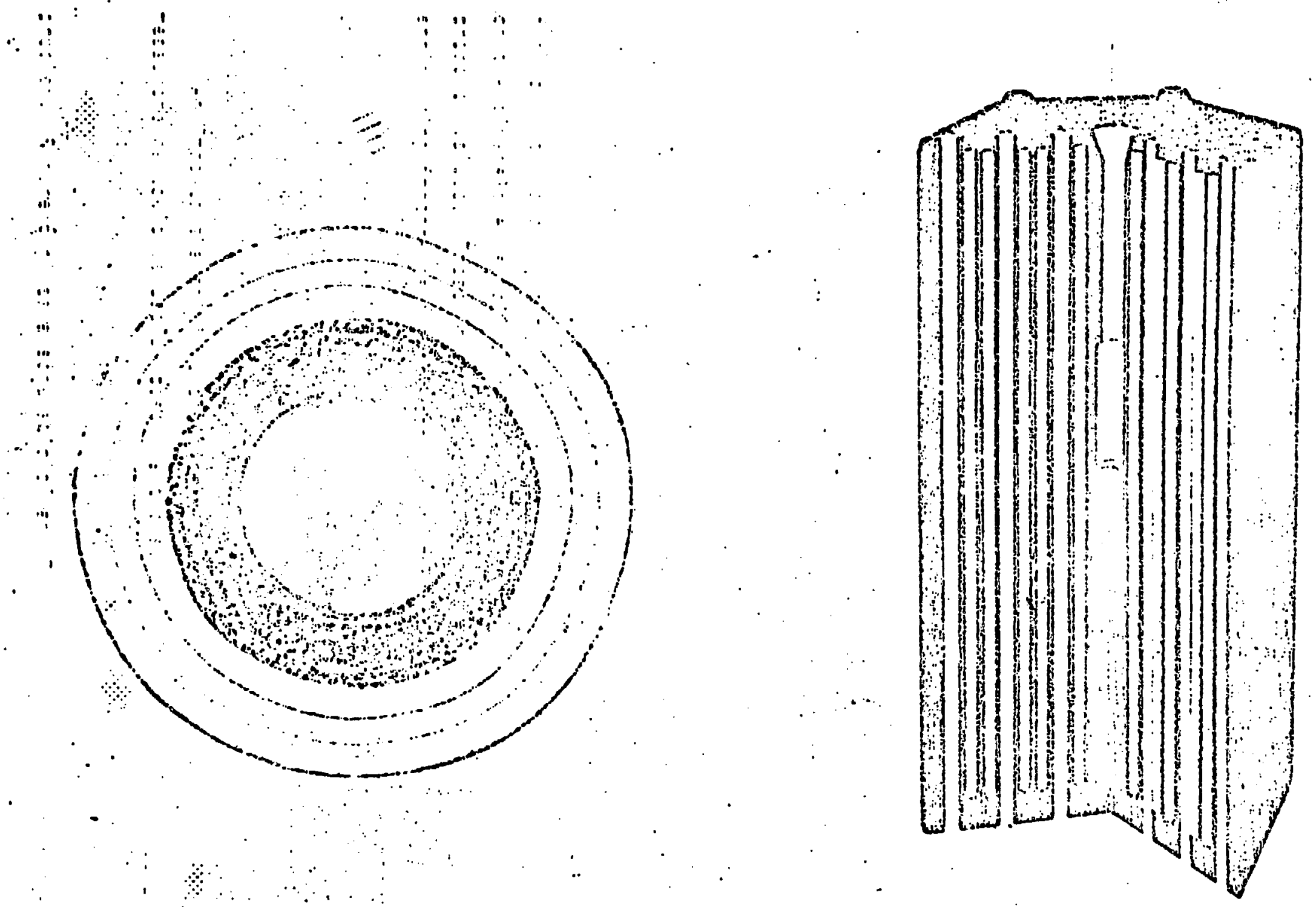


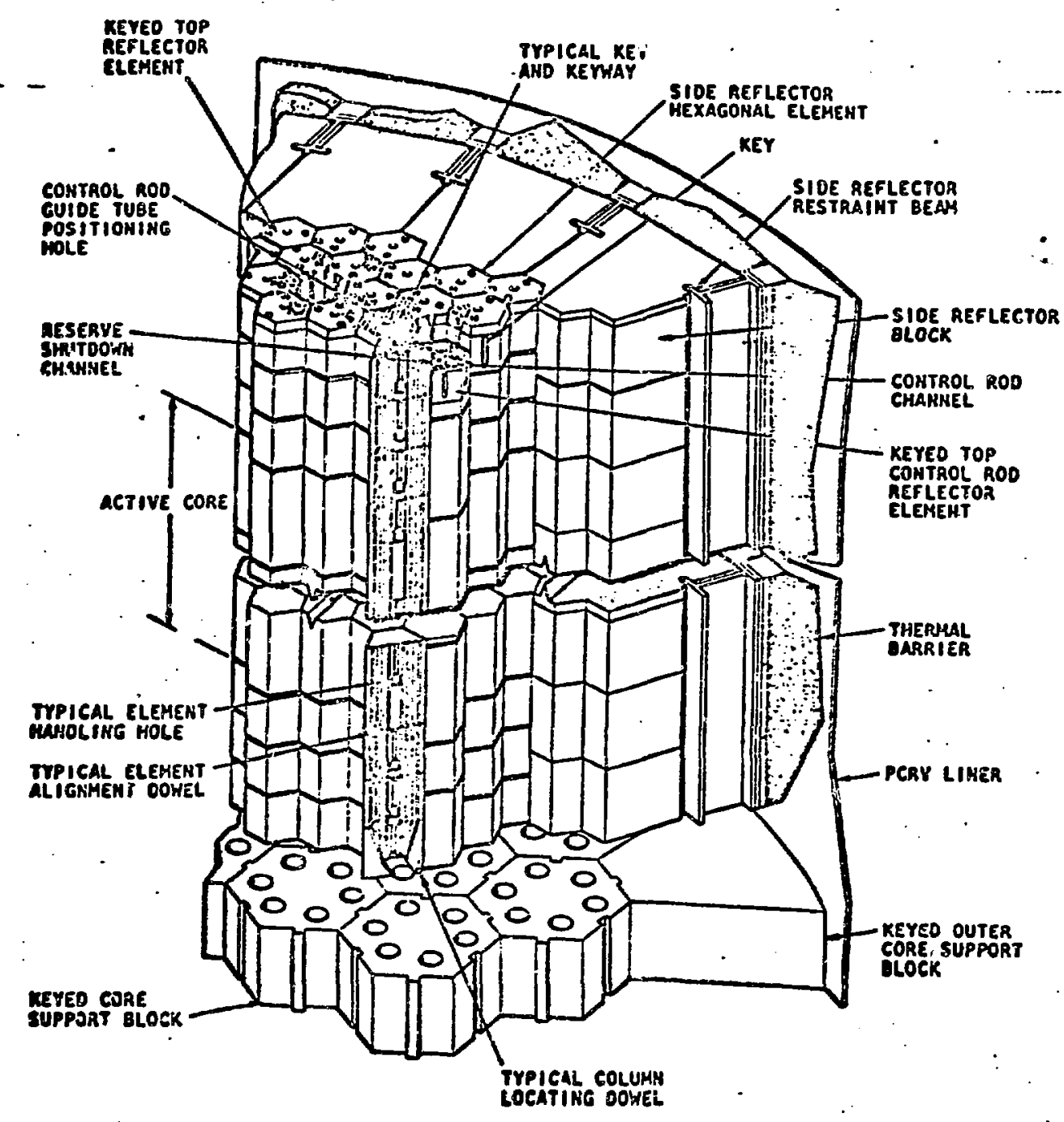

Reector Cora Arzangement 
The performance of the fuel particles is influenced by the operating temperature of the fuel, since radioactive fission products are more difficult to retain at higher fuel temperatures. Thus, a comprehensive thermal analysis is required in designing the reactor core, which takes into consideration the general power distribution, the power peaking factors at fuel gaps and reflector interfaces, the influence of control rod manipulation on power peaking, fuel manufacturing tolerances, flow conditions, and the influence of reactor irradiation on the dimensionai stability of fuel and graphite, as well as on physical property values. These, in general, are interacting efrects. Further, engineering factors have to be considered, sucti as flow maldistribution due to streaning from inlet ducts. This core, as do all nuclear reactors, provides a challenge to the heat transfer specialist.

The steam generator is another component area where complex thermal analysis and expeririental measurements are required. Figure 6 gives a schematic view of an HTGR steam generator. Helium enters near the bottom, passes through the reheater portion, and then down through the superheaterevaporator-economizer sections before exiting and passing upward to the outlet coolant duct. Feedwater enters at about $340^{\circ} \mathrm{F}$ and $3000 \mathrm{psig}$, and leaves at about $950^{\circ} \mathrm{F}$ and $2500 \mathrm{psig.} \mathrm{After} \mathrm{expanding} \mathrm{through} \mathrm{the} \mathrm{high} \mathrm{pressure} \mathrm{turbine,}$ the steam is piped back to the turbine drives of the helium circulators, and then returned to the reheaters at about $625^{\circ} \mathrm{F}$ and $635 \mathrm{psig.} \mathrm{The} \mathrm{hot} \mathrm{reheat}$ steam leaves the steam generators at about $1000^{\circ} \mathrm{F}$ and $575 \mathrm{psig}$ and flows to the intermediate pressure section of the turbine. The heat transfer bundles are generally of a helical coil tube design, as shown in the photograph of a Fort St. Vrain unit, Fig. 7:

The helium coolant temperatures are quite high, entering the steam generator at about $1380^{\circ} \mathrm{F}$ (and $680 \mathrm{psig}$ ), and exiting at about $635^{\circ} \mathrm{F}$. These conditions require careful steam generator design including material selections. The materials used range from carbon steel to nickel-base alloys, depending upon the particular conditions of temperature and pressure, and the materials characteristics with regard to corrosion resistance, weldability, and long-term creep properties. Sufficient allowances in design temperature and material selections need to be made for factors such as temperature unbalances, tube plugging, hot gas streaks, and gas bypass. The helical evaporator tubes present interesting problems in fluid dynamics and heat transfer. 


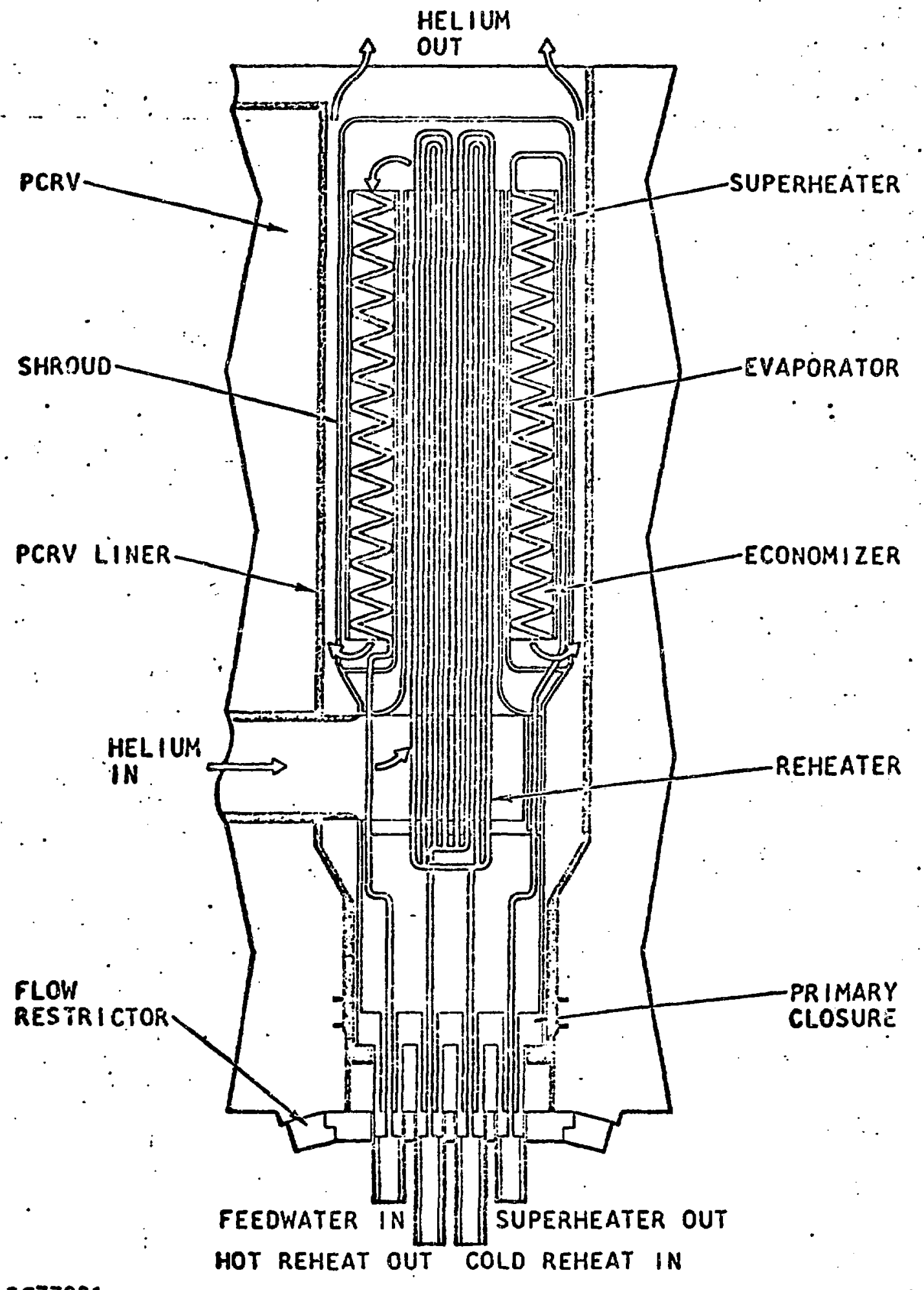

LC77921

F1gure 1100 MW(e) HTGR Plant Steam Generator Concept (U-Tube Reheater) 


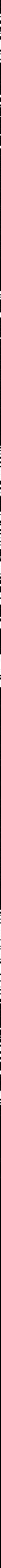


By increasing the outlet coolant temperature of an HTGR to $1500-1600^{\circ} \mathrm{F}$ (from $1400^{\circ} \mathrm{F}$ ), it appears practical to consider use of a helium turbine to drive the generator. Gas turbine use should permit economic application of dry cooling towers thus opening up new sites for power plants. Figure 8 gives a schenlatic diagram of a direct cycle HTGR, in whi hh low temperature energy is rejected from the coolant circuit to a dry cooling tower by means of a water loop.

In general, dry air cooling of a steam plant is costly because of the low temperature of the condensation process by which the steam plant rejects the waste energy. As a result, the thermal driving force is small and large air flows are required. The gas turbine (or Brayton) cycle, however, has a great advantage over the conventional steam (or Rankine) cycle. This is indicated in Fig. 9, which compares the two cycles. In the Brayton cycle, sensible heat rather than latent heat is involved, and the heat rejection is spread over a much wider temperature band. In practice this increases the economically useful cooling air temperature rise some 10 fold, reducing cooling tower area requirements; it also allows an increase in air velocity, which improves heat transfer, further reducing flow needs. A comparison of dry cooling tower requirements for a steam cycle and the direct cycle is shown pictorially in Fig. 10. An attractive alternative for direct cycle heat disposal would be a low temperature heat use such as for desalting water.

Further increase in outlet coolant temperatures to $1600-2000^{\circ} \mathrm{F}$ might permit HTGRs to be used as an energy source for high temperature process heat. Under such circumstances, extensive investigations would be needed in the development of high temperature design criteria, and in the development of high temperature materials which could be used to transfer energy to hydrogen.

Fuel development today permits reliable-operation for the required exposure to fast neutrons and fuel burnup at fuel temperatures of $2200-2400^{\circ} \mathrm{F}$. This provides for the gas temperatures of $1400^{\circ} \mathrm{F}$. Experimental fuel has operated successfully up to $2900^{\circ} \mathrm{F}$ and some tests have been conducted to $3500^{\circ} \mathrm{F}$. One fuel particle tested for the full operating requirement is shown after irradiation in Fig. 11.

Let us now turn to cas-Cooled Fast Breeder Reactors (GCFER). Work on GCFBRs has been under way for about 10 years, supported by the USAEC, 


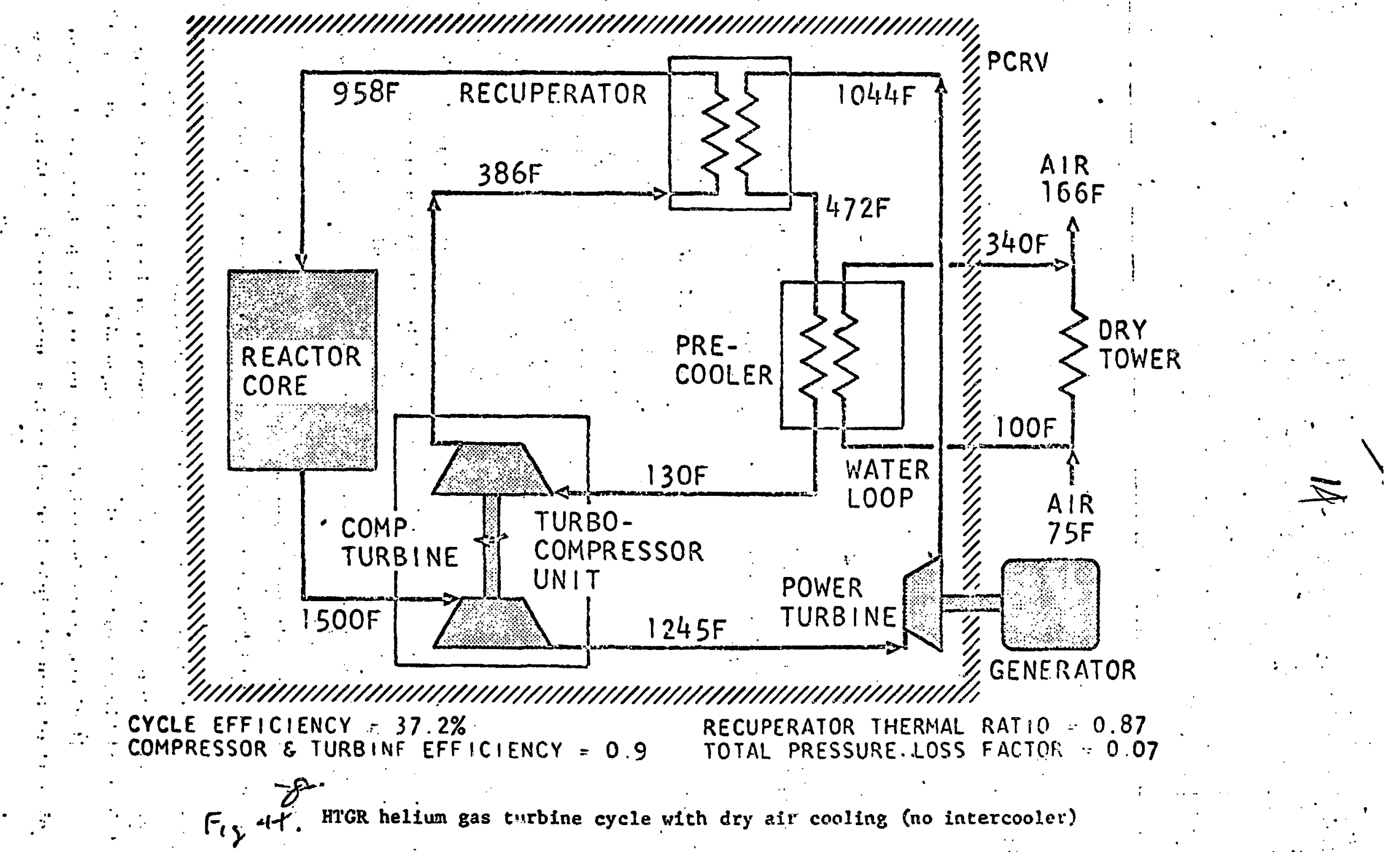




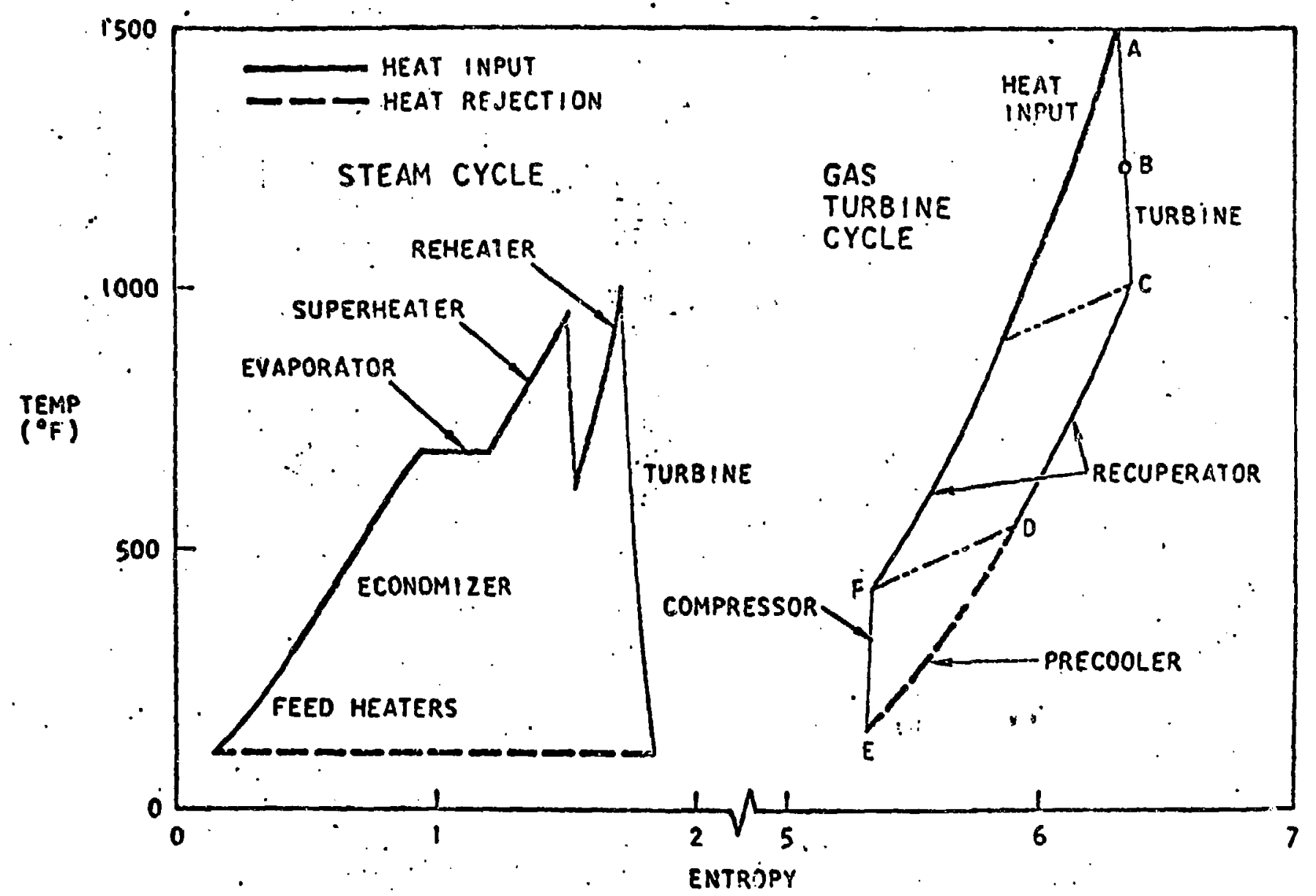

firte Comparison of steam cycle with gas turbine cycle 

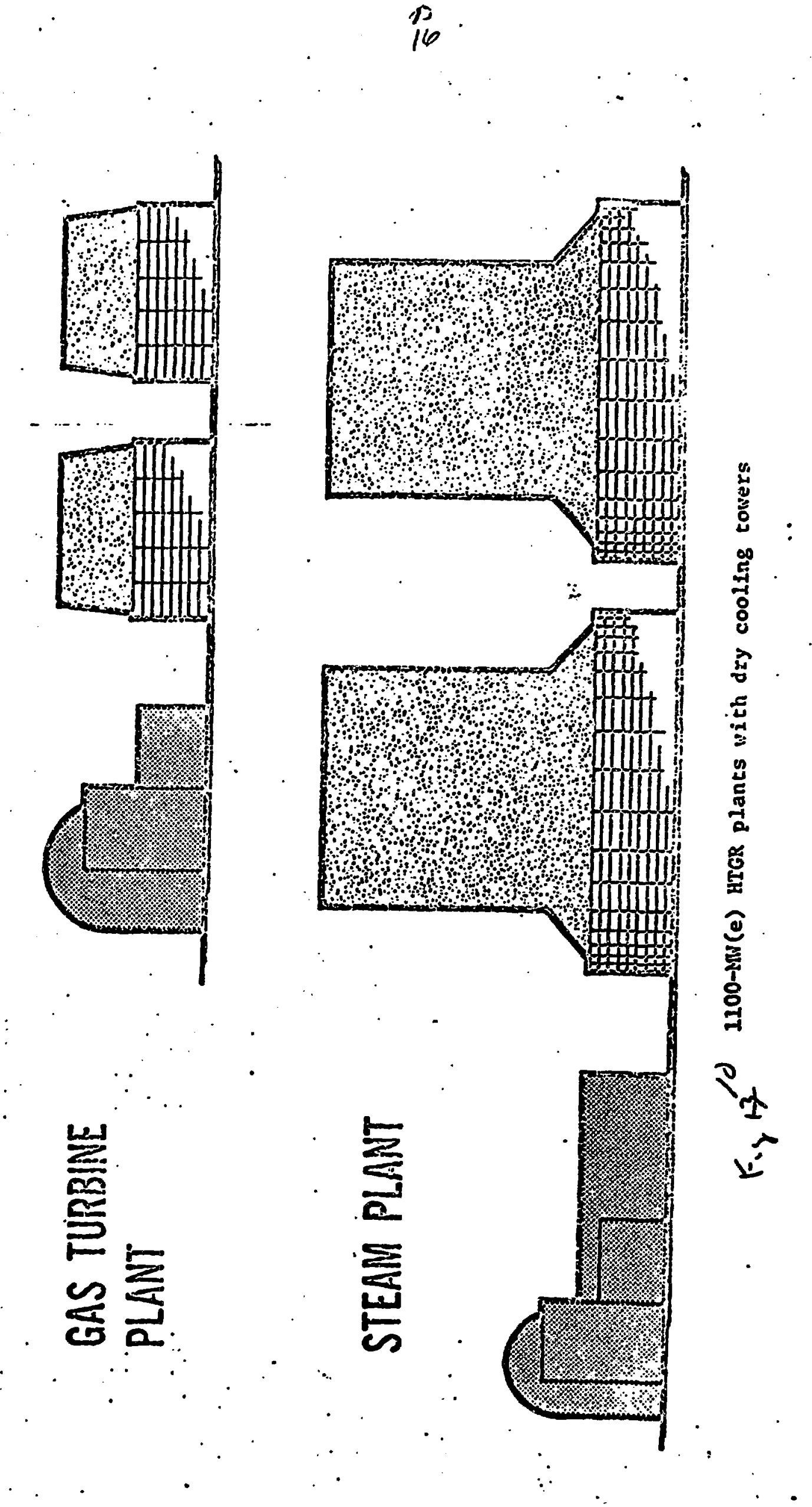


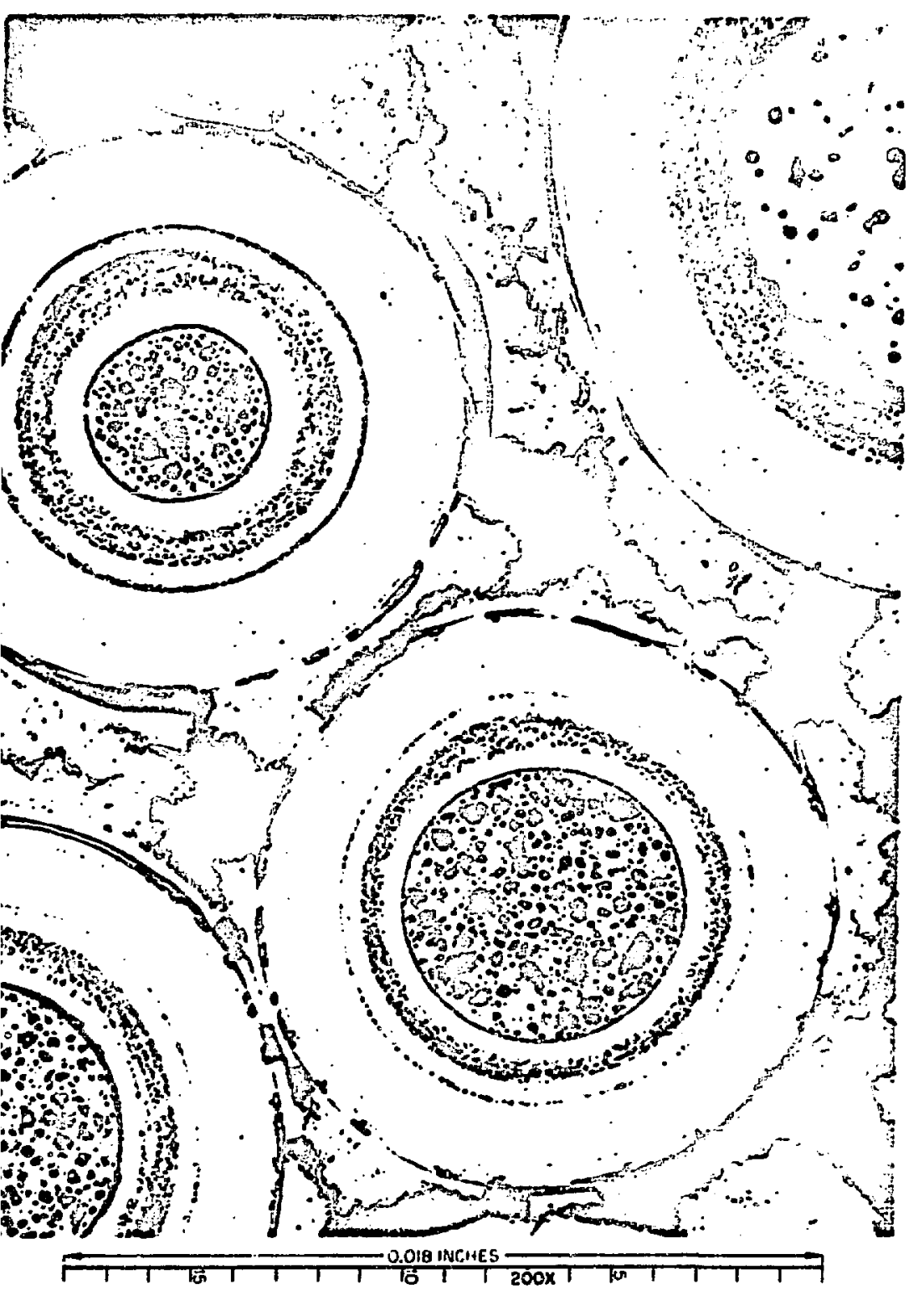

R52969

Tigll. HRB-1. (Th,U)O $\mathrm{O}_{2}-22$ at $\%$ burnup $-1300^{\circ} \mathrm{C}-5.8 \times 10^{21} \mathrm{n} / \mathrm{cm}^{2}$ (fast) 
a group of electric utility companies, and Gulf General Atomic. Since 1968, the effort has concentrated on the design and safety analysis of a demonstration plant.

Some of the design parameters of a 300-MW(e) GCFBR demonstration plant are given in Table 2 along with corresponding values for a large plant. The main features of the reactor plant are shown in Fig. 12. You will note the similarity between this layout and that of the HTGR. The entire primary system is enclosed in the PCRV, with the core, blanket and shield within the central cavity, and the circulators and the steam generators in PCRV wall cavities. In the 300-MW(e) demonstration plant design, there are three main loops and three auxiliary loops for backup cooling. Each main circulator is driven by steam turbines in series with the steam generator, while each auxiliary circulator is driven by an electric motor.

The all-encompassing concrete pressure vessel and auxiliary cooling systems are essential to the safety and viability of this reactor system. In contrast to the HTGR, the full structure in this core has little heat capacity and the helium is much denser than water or sodium. Thus it is essential that coolant circulation be maintained rellably to remove the decay energy afterheat. For some time, it was widely held that the cooling system reliability requirements would exceed practical limits. However. studies during recent years have indicated that the emergency cooling requirements may be no more severe than for water-cooled reactors.

The reactor fuel assembly is composed of 210 hexagonal core and blanket elements, each about $10 \mathrm{ft}$ long and $61 / 2 \mathrm{ln}$. across flat. (Fig. 13) Adjustment of the orifices in these elements distributes coolant flow so as to levelize cladding hot spot temperatures. Pressure in the fuel rods is essentially the same as in the primary coolant by use of a pressure equalization system to eliminate pressure-differential stresses on the cladding. It also $11 \mathrm{mits}$ the release of activity to the primary coolant from falled rods and allows for detection of failed cladding. + , +

The fuel cladding is artificlally roughened to double the local heat transfer coefficlent, at a cost of about tripling the local friction factor. However, the heat transfer coefficients need further experimental verification, particularly for abnormal operating conditions le.g., low 


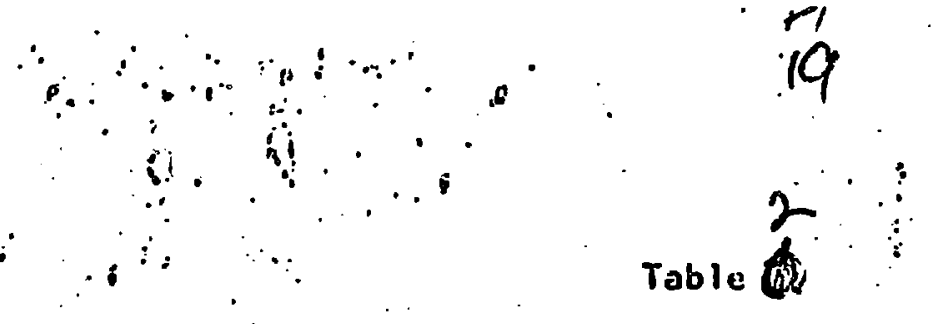

GMAIN DESIGN PARAMETERS FOR GCFR PLANTS

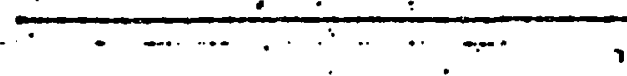

, -

Commercial
Demonstration (Typisal)

Operazing Conditions.

Size, Mu(c)

Helium temperatures, ${ }^{\circ} \mathrm{C}$

Helium pressure, atm (psi)

Cladding hot spot temperature, ${ }^{\circ} \mathrm{C}$

Relative system pressure drop, \%

311

$310-540$

$85(1250)$

690

4.8

3200

0.71

1.15

18.5

37.6

0.60

0.24

Het thermal efficiency, \%
Average fuel rating, $M W(t) / \mathrm{kg}$ (Fissile)

Average power density, $\mathrm{kW}(\mathrm{t}) / \mathrm{liter}$ (core)

Maximum linear rating with $10 \%$ overpower, $W / \mathrm{cm}$ (kW/ft)

Conversion ratio

Fuel life (ful) power days)

Doubling time, years

Maximuiri burnus, MWD/tonne
$460(13.9)$

1.33

690

18

100,000
38

1000

$290-595$

$.85(1250)$

750

4.8

6240

0.60

1.10

16

1.2

0.375

$545^{\circ}(16.5)$

1.5

440

7.

100,000 


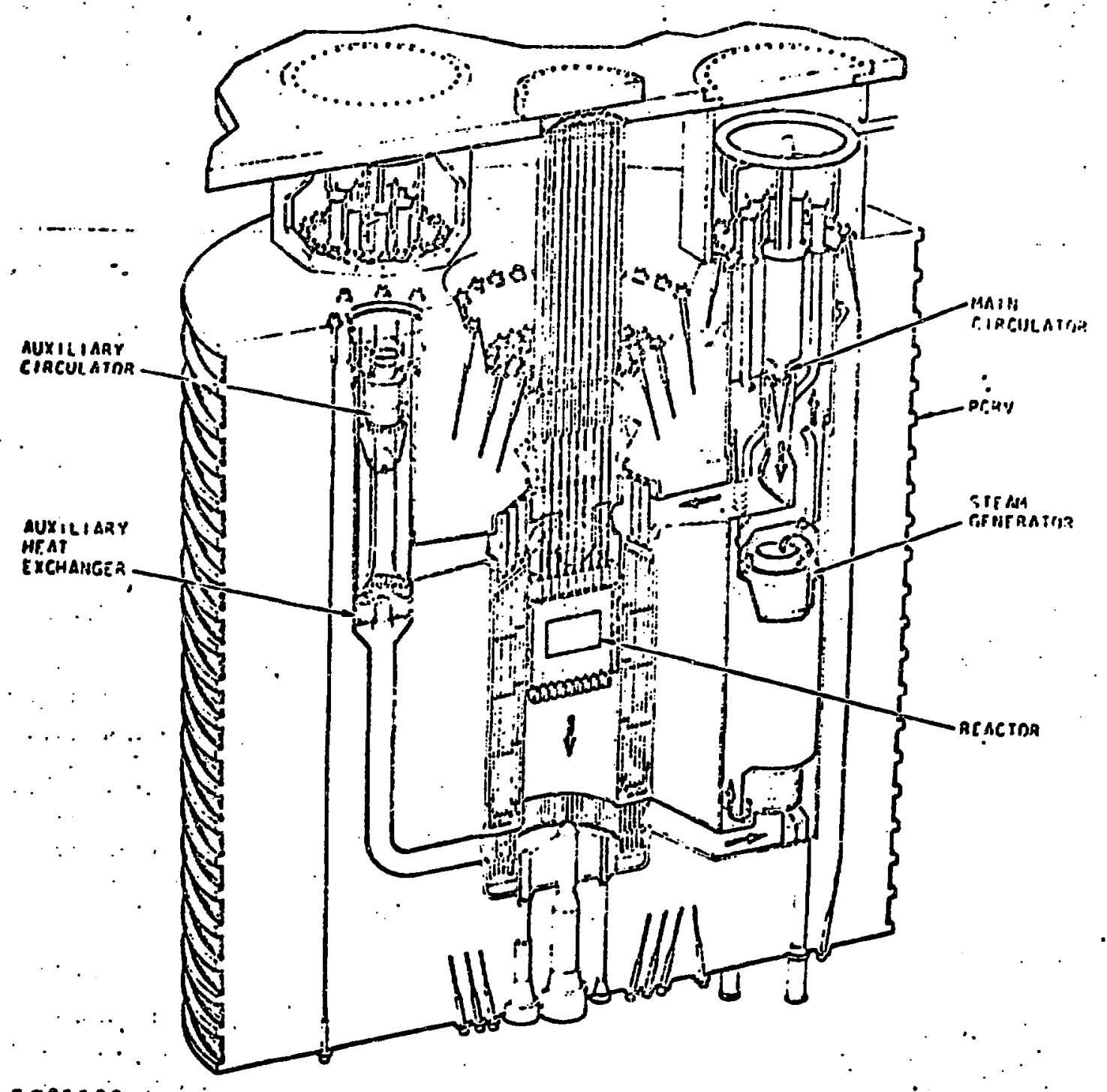

LCC1109-A

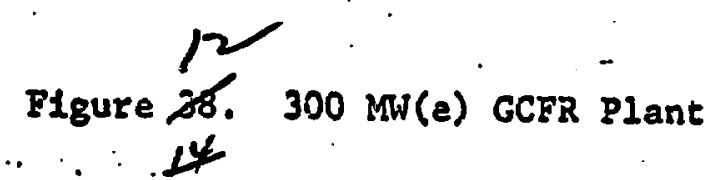



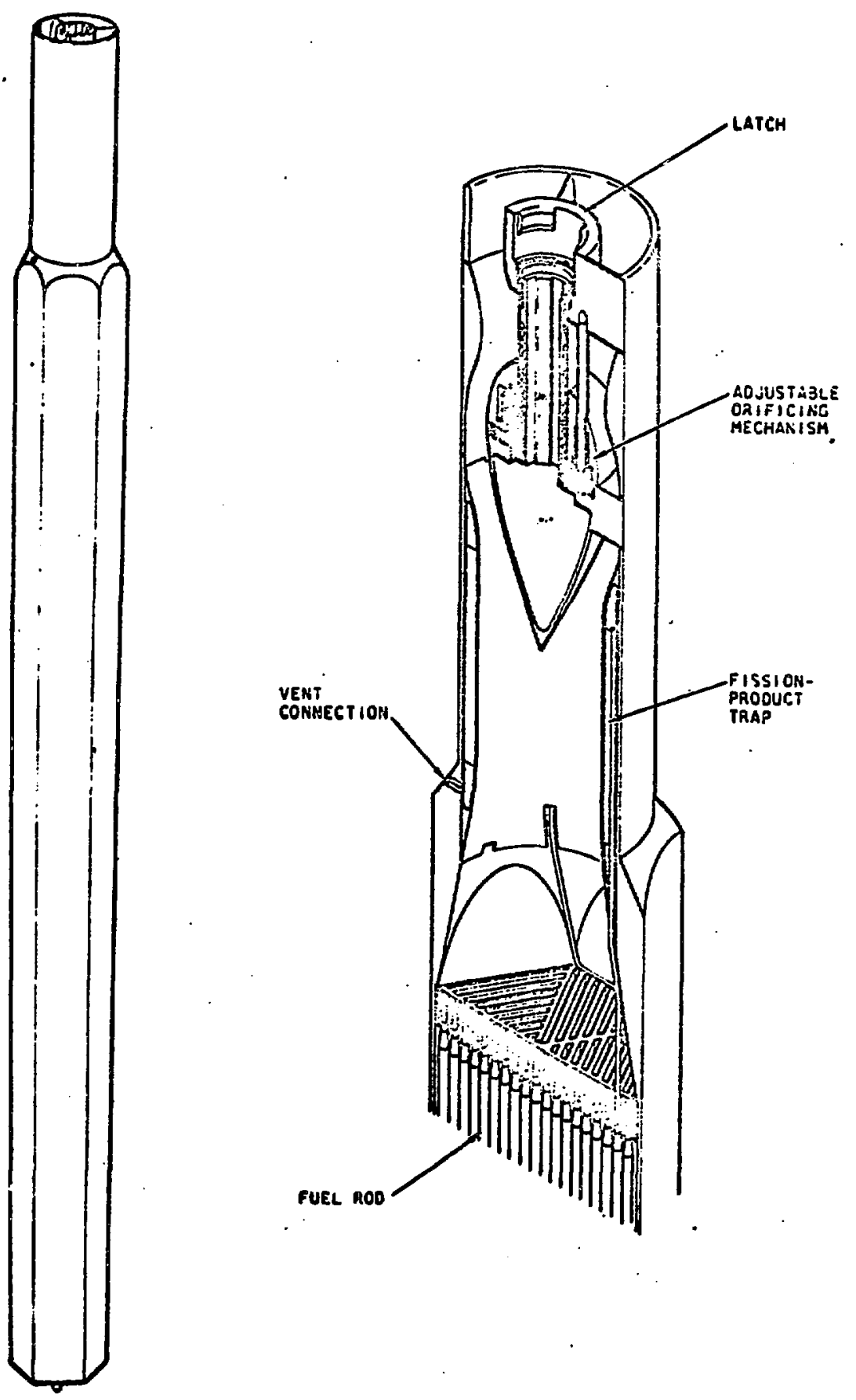

GCFR vented fuel element 
coolant f(low). These latter studies would concern the ability to cool the core under possible accident conditions.

The principal components of the power cycle are shown schematically in Fig. 14. Note that the generated steam goes directly to the steamturbine drive of the circulator, which should provide a high degree of reliability for providing coolant flow through the core.

Thermal evaluation of the GCFBR core involves many of the same factors as for the HTGR; however, since a clad element design is involved, the correspondence is not exact. Thermal features are influenced by power distribution, coolant flow distribution, orificing factors, changes in power distribution with time, mechanical tolerances, thermal deformations of core structures, flow redistribution due to power density gradients, and effects of inner subchannel flow. Further, the prediction of heat transfer coefficients depends upon the effect of turbulence promoters, surface roughening, and fuel pin spacers. Further, fuel temperatures are influenced by the thermal conductivity of the fuel, rad?ation damage effects, the generaiton of fission products, the fuel and cladding dimensional changes with irradiation, gas gaps occurring between fuel and cladding, changes in fuel properties with irradiation, and thermal cycling effects. Engineering factors which need to be considered are maldistribution of flow, mechanical tolepances, fuel enrichment tolerances, and uncertainty of heat transfer coefficients.

Reactor performance improvement can be obtained by use of more sophisticated fuel zoning and flow orificing to give a more uniform power distribution whd temperature rise through the core, at the expense of higher fuel enrichment requirements, use of higher working pressures, use of figher pumping power, or tighter thermal tolerances.

Fuel swelling Juring reactor irradiations will change flow cross sectional areas, which in turn will influence flow distributions in the core. This will influence heat transport as well as heat transfer, and also the temperatures in the core. Since permissible core temperatures are limited, thermal designs have to properly account for these factors. Insulation problems are similar in the GCFBR as in the HTGR except since the coolant temperature is somewhat lower, these problems are probably less severe. Steam generator design problems are similar, although the design conditions for the GCFBR are more stringent due to the lower 


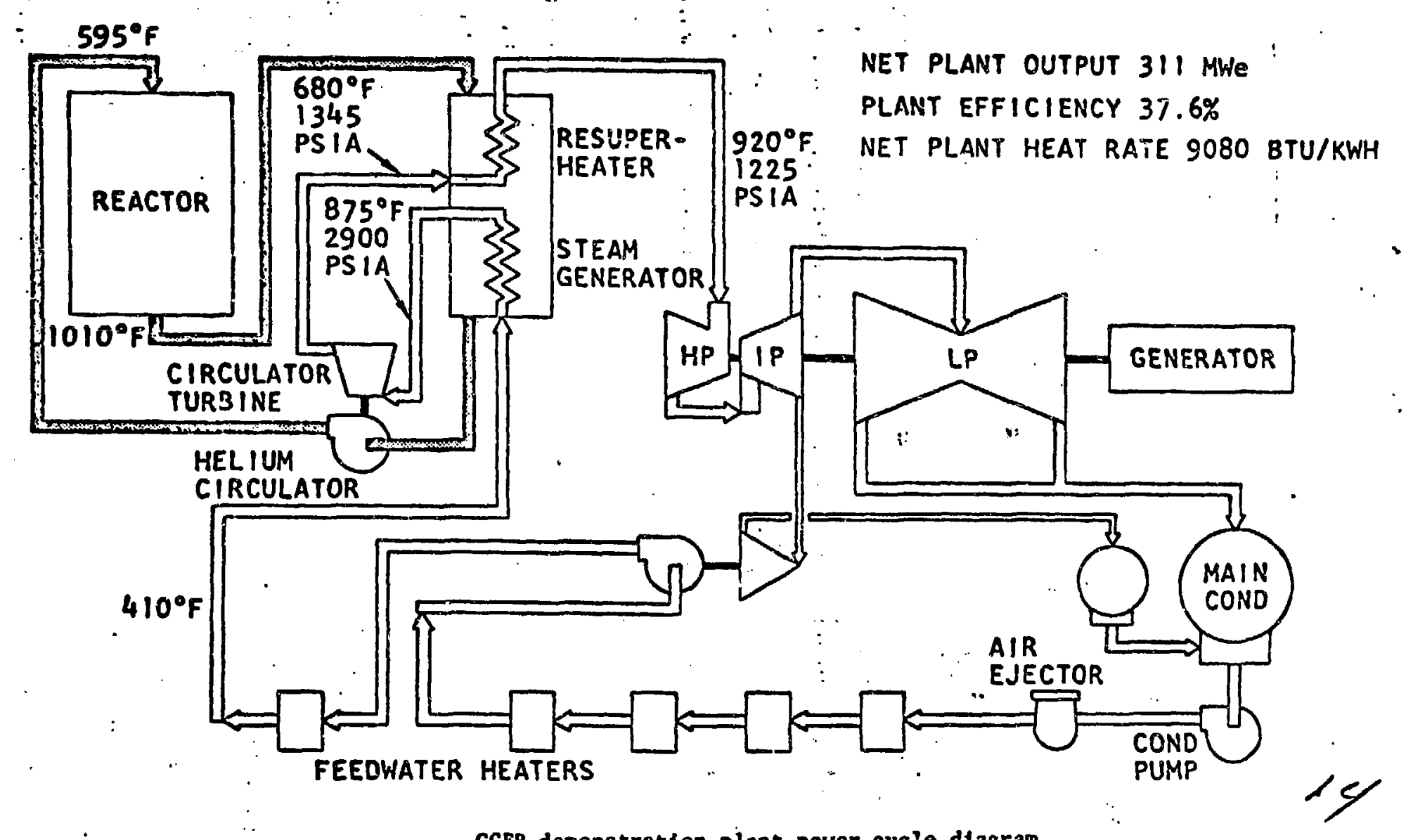

$\&$

i. .

GCFR demonstration olant oower cvcle dlapram 
coolant outlet temperature, which places more emphasis on obtaining a high performance steam generator so as to improve steam conditions. Thus, heat transfer coefficients in steam generators need specific evaluation under GCFBR conditions.

Another feature associated with GCFBRs is the transparency of the coolant to gamma radiation. Because of this, a thermal shield has to be provided which permits helium to flow and yet protects ducts from high irradiation doses. This is not directly related to thermal evaluation, but it is related to coolant flow pressure drops, which in turn have an influence on thermal design.

In summary, gas-cooled reactors are a commercial reality with apparent possibility for substantial improvement. Much of this potential must derive from further studies and testing in heat transfer and fluid dynamics. If realized, the capabilities of gä-cooled reactors can exceed those of any other reactor system. The HTGR capability for using either thorium or plutonium as fue!, its potential for the steam turbine or gas turbine energy cycle, and its potential for dry cooling.towers and process heat applications make it the most versatile of all reactors. When the HTGR is combined with the GCFBR (which has the highest breeding potential) these reactors offer a very attractive power system. Although I have emphasized the development requirements, hopefully in response to heat transfer interests, the total development requirements are not exsessive. This derives from the similarities between the thermal and breeder designs and the capability of the gas breeder to ulilize sodium-cooled reactor fuel experience.

In this talk I have given the general features of HTGRs and GCFBRs, their interrelation and their future applications, and also some of the thermal features which need additional investigation in order to improve the design and performance of these systems. While this overall view has been rather sketchy, I hope it stimulates you to look more deeply into pertinent thermal studies.

Thank you. 


\section{BIBLIOGRAPHY}

D。B. Trauger, Helium-Cooled Reactors, USAEC Report ORNL-TM-2297, Oak Ridge Nationa! Laboratory, October 1968.

U. S. Atomic Energy Commission, The Use of Thorium in Nuclear Power Reactors, USAEC Raport WASH-1097, pp. 51-54, June 1969.

P. U. Fischer, 5. Jaye and H. B. Stewart, Alternate Fuel Cycles for the HTGR, Proceedings of a Symposium, Advanced and High-Temperature Gas-Cooled Reactors, Julich, 21-25 October 1968, Pp. 745-760, IAEA, Vienna, 1969.

U. S. Atomic Energy Commission, An Evaluation of Alternate Coolant Fast Breeder Reactors, USAEC Report WASH-1090, pp. 55-62, April 1969.

A. J. Goodjohn, High-Temperature Gas-Cooled Reactor's Using Helium Coolant, Helium Symposia Proceedings in 1968 - A Hundred Years of Helium, pp. 117133, U. S. Department of the Interior, Bureau of Mines, 1969.

H. W. Müller, C. B. von der Decken, U. Hennings and W. Sturmer, The AVR Pebble Bed Reactor, paper presented at the British Nuclear Energy Society Symposium on High Temperature Reactors and the Dragon Project, 23 May 1966.

UHTREX: Alive and Running with Coolant at $2400^{\circ} \mathrm{F}$, Nucl. News 12, pp. 31-32, November 1969.

R. E. Walker and T. A. Johnston, Fort St. Vrain Nuclear Power Station, Nucl. Eng. Int1. Pp. 1069-1093, December 1969.

H. W. Müller, Design Features of the 300-MW THTR Power Station, Proceedings of a Symposium, Advanced and High-Temperature Gas-Cooled Reactors, Julich 21-25 October 1968, pp. 135-152, TAEA, Vienna, 1969.

Warld Digest, Nucl. Eng. Intl. pp. 614, August 1969.

A. L. Lotts and R. G. Wymer, Economics and Technology of HTGR Fuel Recycle, Proceedings of a Symposium, Advanced and High-Temperature Gas-Cooled Reactors, Jülich, 21-25 October 1968, PP. 789-812, TAEA, Vienna, 1969.

K. G. Hackstein, M. Hrovat, G. Spener and K. Ehlers, Recent Developments in the Manufacture of Spherical Fuel Elements for High-Temperature Gas-Cooled Reactors, Proceedings of a Symposium, Advanced and HighTemperature Gas-Cooled Reactors, Jülich, 21-25 October 1968, Pp. 673-679, TAEA, Vienna, 1969.

H. J. Stocker, W. Delle, K. D. Olshausen, G. Pott, K. Ehlers, E. Groos and L. Valette, Fuel and Material Testing for Pebble-Bed Reactors, Proceedings of A Symposium, Advanced and High-Temperature Gas-Cooled Reactors, Jülich, 21-25 October 1968, PP. 681-690, TAEA, Vienna, 1969.

O.E.C.D. Dragon High Temperature Reactor Project, Tenth Annual Report, 1968-1969, pp. 53-74. 
J. L. Scott et al., Development of Bonded Beds of Coated Particles for HTGR Fuel Eilements, Proceedings of Gas-Cooled Reactor Information Meeting, Oak Ridge, April 27-30, 1970, USAEC Report CONF-700401.

G. E. Lockett and S. B. Hosegood, Design Concepts for Power Reactors, British Nuclear Energy Society, Eymposium on High Temperature Reactors and the Dragon Project, Session IV, paper 13, 24 May 1966, Winfrith, Dorset England.

D. C. Morse and H. K. Wiard, Reactor Arrangement Studies for a Large HTGR Plant, USAEC Report GA-8439 (Rev.), Gulf General Atomic, July 31, 1969.

R. E. D. Burrow and A. J. Williams, Hartlepool AGR, Nucl. Eng. Intl., pp. 973-995, November 1969.

D. J. Silverleaf and R. J. Weeks, The Performance of the Central Electricity Generating Board Nuclear Power Stations, Proceedings of a Symposium, Advanced and High-Temperature Gas-Cooled Reactors, Jülich, 21-25 October 1968 , pp. 51-73, IAEA, Vienna, 1969.

Masao Andoh, AGR-HTR Coaxial Cores for Steelmaking, Nucl. Eng. Intl., pp. 1094-1096, December 1969.

Session III, The Application of Gas Turbines, Proceedings of a Symposium, Advanced and High-Temperature Gas-Cooled Reactors, Julich, 21-25 October 1968, pp. 247-406, IAEA, Vienna, 1969.

Farrington Daniels, Suggestion for an Experimental Power Reactor. An Impregnated Graphite, Nitrogen-Cooled Reactor and Gas Turbine, Using Materials and Equipment Available Now, USAEC Report AECD-4095, Argonne National Laboratory, April 1950.

E. Böhm, W. Twardziok, H. Oehme and H. Weiskopf, Development Work for Large Scale Helium Turbine Plants with High Temperature Reactors, Proceedings of Gas-Cooled Reactor Information Meeting, Oak Ridge, April 27-30, 1970, USAEC Report CONF-700401.

D. B. Coburn, The Gas-Cooled Fast Breeder Reactor Why and When, USAEC Report GA-8811, Gulf General Atomic, Aug. 21, 1968.

H. G. O'Brien and O. W. Burke, Loss-of-Cooling Accidents and Core Cooldown Rates in a Gas-Cooled Fast Reactor, USAEC Report ORNL-TM-2783, Oak Ridge National Laboratory, Dec. 1, 1969.

C. P. Gratton, E. G. Bevan, A. T. Hooper and G. W. Horsley, A Gas-Cooled Fast Reactor with Direct-Cycle Potential, Proceedings of a Symposium, Advanced and High-Temperature Gas-Cooled Reactors, Jüilch, 21-25 October 1968, pp. 359-383, IAEA, Vienna, 1969.

J. W. Landis et ai., Gas-Cooled Reactor Development in the Uni ted States, paper presented to the Fourth United Nations International Conference on the Peaceful Uses of Atomic Energy, Geneva, Switzerland, September 6-16, 1971.

H. B. Stewart et al., Utilization of the Thorium Cycle in the HTGR, paper presented to the Fourth United Nations International Conference on the Peaceful Uses of Atomic Energy, Geneva, Switzerland, September 6-16, 1971. 